\title{
Patterns of energy substrate utilization in overwintering painted turtles, Chrysemys picta
}

\section{Kenneth M. Crawford}

Department of Biology, University of Michigan, Ann Arbor, MI 48109, U.S.A.

The amounts of energy liberating substrates in muscle, heart, liver and total carcass were determined in painted turtles just prior to (early October) and upon arousal from (late March) hibernation. Between the fall and spring samples, total carcass neutral lipids, protein and glycogen were depleted $37.8 \%, 11.0 \%$ and $70.2 \%$, respectively. Total carcass lactate increased $551 \%$ in post-hibernatory turtles suggesting an important role for anaerobic glycolysis in producing energy during periods of anoxia. Females used more energy than males; however, the pattern of substrate utilization was similar in both sexes with lipid, protein and glycogen providing $56 \%, 27 \%$ and $17 \%$ of the energy, respectively.

Key words: Energy substrate utilization; Chrysemys picta.

Comp. Biochem. Physiol. 109A, 495-502, 1994.

\section{Introduction}

Seasonal variation in activity is a conspicuous aspect of the biology of reptiles and amphibians. At cold temperatures they typically overwinter in thermally stable refugia where they may remain dormant for extended periods of time. Long periods of dormancy at low temperature must involve physiological adjustments and certainly influence the ecology and life histories of these animals, but the biology of hibernating individuals has been infrequently explored.

The painted turtle ranges farther north than any other species of turtle in North America (MacCulloch and Secoy, 1983). In southern Michigan, in late September or early October, when water temperatures fall

Correspondence to: K. M. Crawford, Department of Anatomy and Cell Biology, University of Michigan, Ann Arbor, MI 48109-0616, U.S.A. Tel. 313-763-4772; Fax 313-763-1166.

Received 2 December 1993; accepted 21 February 1994. below $10^{\circ} \mathrm{C}$, Chrysemys picta cease feeding and turtles soon become torpid, remaining dormant until mid-March (Sexton, 1959; Gibbons, 1968). However, other reports suggest some movements by turtles during this period (see Ultsch, 1989, for a review). In southeast Pennsylvania, hibernating eastern painted turtles (C. picta picta) were found buried in the soft bottoms of ponds and marshes (Ernst, 1972). Cloacal temperatures of hibernating turtles averaged $6.2^{\circ} \mathrm{C}$. Taylor and Nol (1989) reported very similar results for painted turtles hibernating in southern Ontario. Arousal of painted turtles in southeast Michigan typically occurs in mid-late-March after surface ice melts (Sexton, 1959). Specific environmental cues stimulating arousal of aquatically hibernating turtles are complex and not well understood (Crawford, 1991).

At the northern extent of their range, painted turtles may be aphagic for 6-7 months and may be submerged in ice covered bodies of water without the benefit of 
aerial respiration for up to 4 months during the annual cycle. During hibernation, turthes must rely on endogenous sources of energy to support metabolism. The purpose of this investigation was to evaluate the patterns of energy substrate utilization of painted turtles $C$. picta marginata during hibernation. This was determined by measuring the body and tissue composition of energy substrates prior to hibernation and upon arousal.

\section{Materials and Methods}

Forty-eight midland painted turtles, Chrysemys picta marginata were collected at Mill Pond in Pinckney, (Livingston Co.) Michigan. Fall (pre-hibernatory) turtles were collected using basking traps between 30 September and 3 October 1983. Spring (post-hibernatory) turtles were collected using a dip-net between 23 and 26 March 1982. Spring turtles were just becoming active at Mill Pond when they were captured, many just emerging from the sediment or floating in the water column. Newly aroused turtles were lethargic upon capture. Immediately after capture, turtles were frozen in a dry-ice ethanol bath, and stored at $-20^{\circ} \mathrm{C}$ until analysis.

Fall and spring samples were further subdivided by sex and for scparate body compositional analysis. Turtles were assigned to a particular group so as to minimize any difference in body size. Within a sex, there were no significant differences in body mass in any group in the analysis. Total body water, neutral lipid and protein were determined for one group, whereas the other group was assayed for total body glycogen, glucose and lactate as well as tissue glycogen.

For determination of body water, lipid and protein, frozen turtles were sliced transversely into $1 \mathrm{~cm}$ pieces and dried to constant mass in a $75^{\circ} \mathrm{C}$ oven. Total body water was determined gravimetrically as the difference between mass at capture and dry mass. The dehydrated slices were ground into small pieces with a mortar and pestle and placed in dry, pre-weighed extraction thimbles (Whatman, Maidstone,
U.K.). Neutral lipid was then extracted with petroleum ether in a Soxhlet Apparatus for $24 \mathrm{hr}$. Total neutral lipid was determined gravimetrically as the difference between dry mass and lean dry mass. The lean dry tissue was then solubilized in $1 \mathrm{~N}$ $\mathrm{NaOH}$ for 7 days with stirring. Duplicate aliquots of the supernatent were analyzed for protein using the modified Biuret Assay with bovine serum albumin as the standard.

Turtles in the carbohydrate group were thawed at $5^{\circ} \mathrm{C}$ for $24 \mathrm{hr}$ and their pectoralis major muscle, heart ventricle, right lobe of the liver and entire gastrointestinal tract were dissected from the animal and frozen for subsequent analysis. The remaining carcass was deshelled and also frozen. Examination of gut contents of the spring turtles revealed no food material. Fall turtles were still active upon capture, and some individuals had small amounts of material in the lower intestine, but rarely any in the stomach or proximal section of the intestine.

Tissue samples were homogenized in $0.6 \mathrm{~N}$ perchloric acid with a tissumizer (Tekmar, Cincinnati, OH). Frozen deshelled carcasses were chopped into small pieces and homogenized in perchloric acid with a Waring blender. Aliquots from the blender were further homogenized with the tissumizer. Homogenates were analyzed for frec glucose, glycogen and lactate.

Glycogen content was determined as glucose after treatment of the homogenate with amyloglucosidase (AGS) at a final concentration of $140 \mathrm{U} / \mathrm{ml}$. Glycogen was calculated as the difference between total glucose (after AGS treatment) and free glucose (before AGS treatment). Glucose was assayed spectrophotometrically using a kit from Sigma Chemical (St. Louis, MO). Lactate was assayed spectrophotometrically after complete oxidation with lactate dehydrogenase (LDH), measuring the appearance of $\mathrm{NADH}$ at $340 \mathrm{~nm}$. NAD and $\mathrm{LDH}$ were also from Sigma.

Data were analyzed by ANOVA, as a $2 \times 2$ factorial design with sex and season as factors. In cases of missing values, $B M D P 2 v$ was performed on the data set. Results of statistical tests were considered significant at $P<0.05$. 


\section{Results}

\section{Lipid}

Petroleum ether extractable lipid content of painted turtles was lower upon emergence than in pre-hibernatory turtles of both sexes (Fig. 1). Two-way ANOVA revealed that both season and sex had significant effects on neutral lipid $(P=0.002 ; P=0.046$, respectively). However, the difference between the sexes was significant only in pre-hibernatory animals. Upon arousal, there was no difference in fat content per unit wet mass between males and females (Fig. 1). Males lost $33.5 \%$ of their neutral lipid, whereas females lost $42.1 \%$ neutral lipid between October and March, indicating that upon emergence, turtles retained a substantial reserve of neutral lipid (Fig. 1).

\section{Protein}

Figure 2 illustrates total body protein in pre- and post-hibernatory painted turtles. Season had a significant effect on total body protein $(P=0.0002)$, but there was no difference due to sex $(P=0.49)$. Prior to hibernation, $12.4 \%$ of wet mass of turtles was protein. Upon emergence, total body protein had decreased to $11.0 \%$ of wet mass, representing an $11.0 \%$ decline.

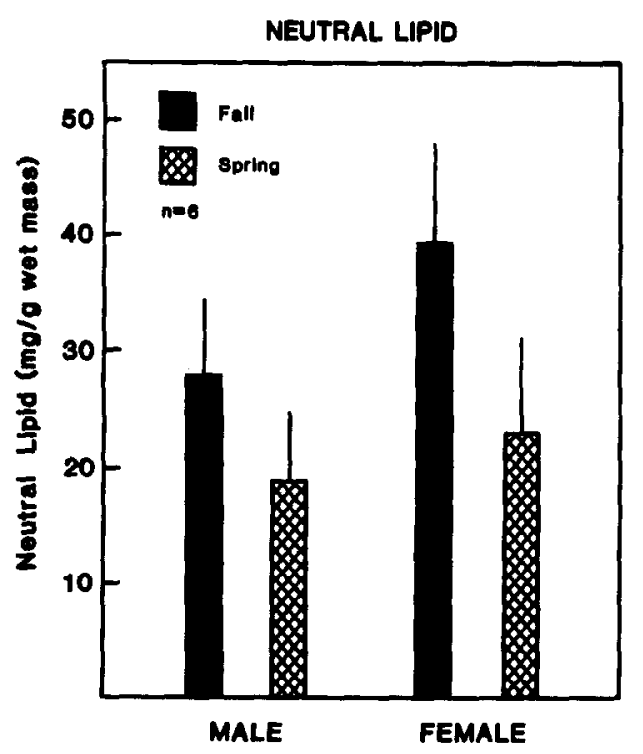

Fig. 1. Neutral (petroleum ether extractable) lipid content (mg/g wet mass) of male and female painted turtles prior to hibernation (fall) and upon emergence (spring). Error bars in this and all subsequent figures represent 1 standard deviation.

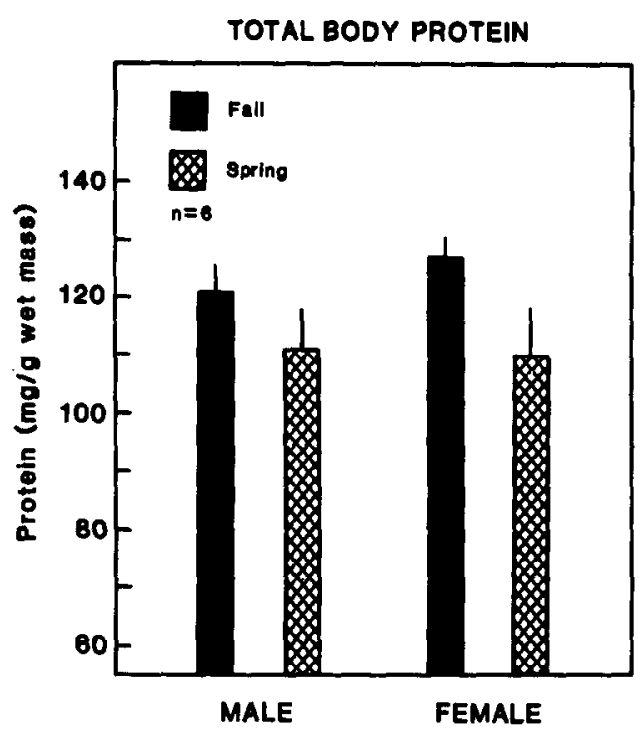

Fig. 2. Total body protein ( $\mathrm{mg} / \mathrm{g}$ wet mass) of male and female painted turtles prior to (fall) and upon emergence (spring) from hibernation. Total body protein was determined using a modification of the Biuret Assay after solubilization of lean dry carcass in 10 volumes of $1 \mathrm{~N} \mathrm{NaOH}$.

Despite this decrease in total body protein, the three tissues examined (pectoralis muscle, heart ventricle and liver) showed insignificant changes in protein content (mg/g wet mass) (data not shown).

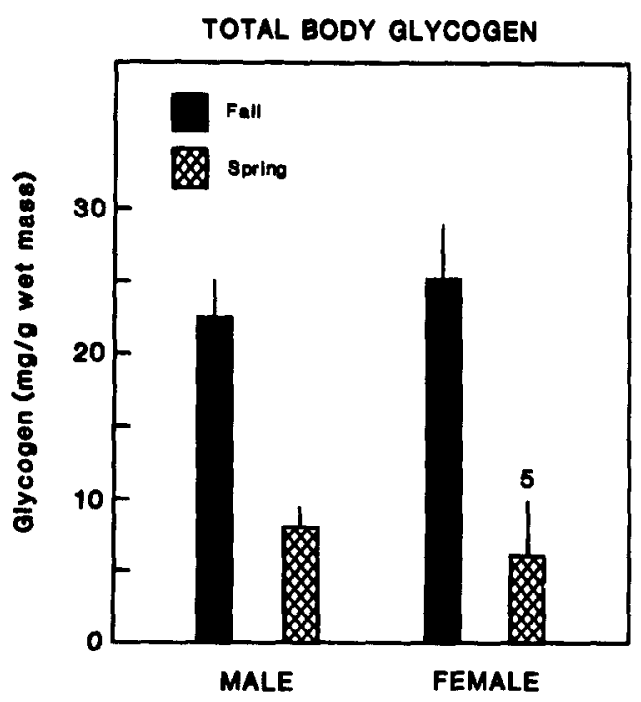

Fig. 3. Total body glycogen (mg/g wet mass) of male and female painted turtles prior to (fall) and upon emergence (spring) from hibernation. Total body glycogen was determined as glucose equivalents from homogenized carcasses after incubation with anyloglucosidase using the glucose oxidase/peroxidase method. Six turtles were used for each determination except where noted. 


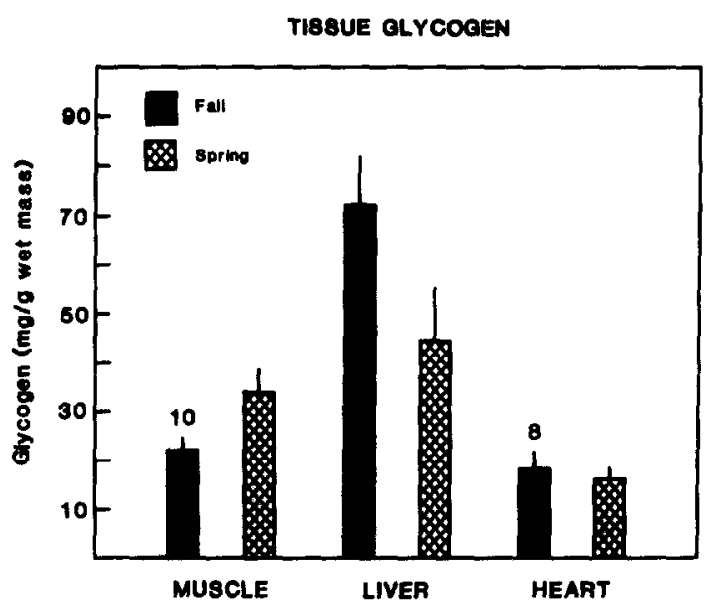

Fig. 4. Glycogen content ( $\mathrm{mg} / \mathrm{g}$ wet mass) of pectoralis muscle, liver and ventricular muscle of all turtles (glycogen content of the tissues did not differ significantly by sex). Twelve turtles were used in each sample unless otherwise noted.

\section{Glycogen}

Total body glycogen decreased between pre- and post-hibernatory turtles (Fig. 3). Although there was no effect of sex on total body glycogen $(P=0.79)$, the effect of season was highly significant $(P<0.0001)$. For all turtles in this study, glycogen decreased $70 \%$ from $2.4 \%$ to $0.7 \%$ of wet mass.

The glycogen content of selected tissues is shown in Fig. 4. Because of a lack of significant effect of sex on glycogen content, data for tissue glycogen were combined for males and females. Liver, of pre- hibernatory turtles, possessed the greatest glycogen content $(7.3 \%$ of wet mass). Of the three tissues, pectoralis muscle, cardiac muscle and liver, only liver showed a significant decline in glycogen content between fall and spring. Pectoralis muscle showed a significant increase in glycogen content (Fig. 4). Cardiac muscle showed no change in glycogen content. All tissues showed significantly higher concentrations of free glucose in turtles upon emergence $(P<0.001)$. Pectoralis muscle, liver, and cardiac muscle displayed 2.8-, 2.2- and 2.3-fold increases in free glucose, respectively.

\section{Lactate}

Between the fall and spring sampling, lactate accumulated in large amounts (Fig. 5). There was no difference between males and females, but the effect of season was highly significant $(P<0.0001)$. Upon emergence in the spring, turtles showed a 5.8-fold increase in total body lactate to a level of $36.5 \mu \mathrm{mol} / \mathrm{g}$ wet mass. The accumulation of lactate was significant in all tissues examined with skeletal muscle, cardiac muscle, and liver demonstrating 4.1, 7.3 and 6.7-fold increases, respectively.

\section{Body water}

Painted turtles collected upon emergence were edematous with respect to pre-hibernatory turtles as body water increased from 64.6 to $68.3 \%$ of body mass (Fig. 6). Season had a significant effect on total body water $(P<0.0001)$, whereas there was no effect of $\operatorname{sex}(P=0.56)$.

As a percent of wet weight, all three major classes of energy substrates decreased (lipid, protein and carbohydrate), whereas water content increased. The increase in water appeared to offset the decreases in energy producing substrates such that the remaining mass, presumably mineral content (bone and shell), nucleic acids and non-neutral lipids remained constant at around $17 \%$ of wet mass. Figure 7

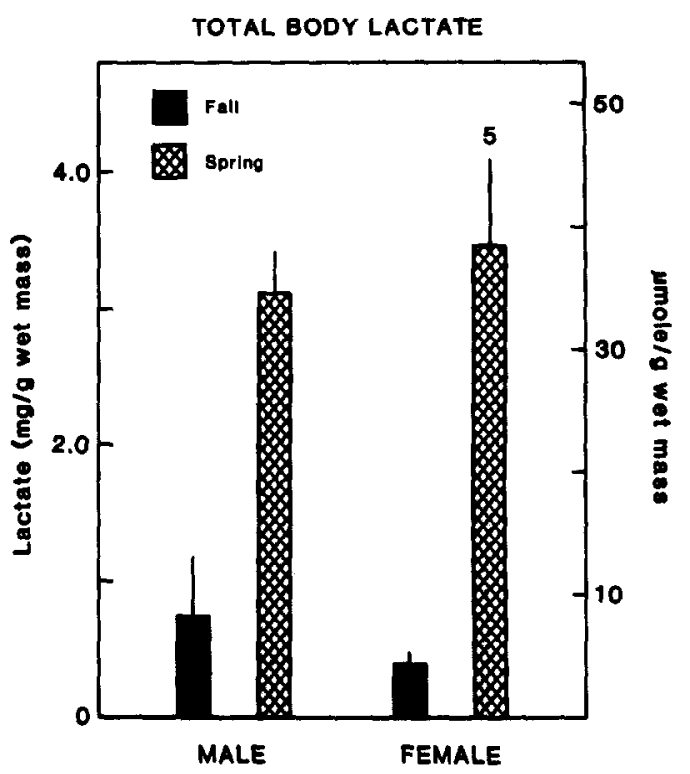

Fig. 5. Total body lactate of painted turtles prior to (fall) and upon emergence (spring) from hibernation. Lactate was determined as the appearance of NADH upon complete oxidation to pyruvate by LDH. Six turtles were used for each determination except where noted. 


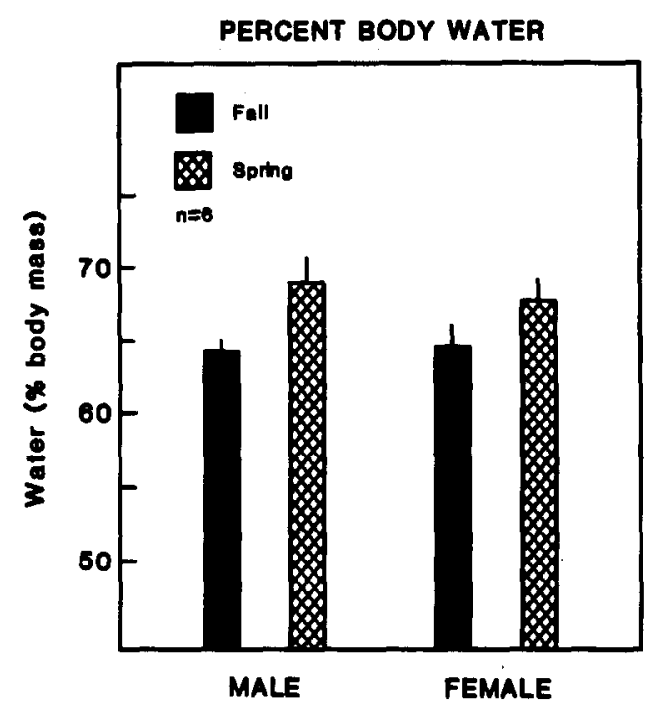

Fig. 6. Total body water ( $\%$ body mass) of painted turtles prior to (fall) and upon emergence (spring) from hibernation. Body water was determined gravimetrically as the difference in mass before and after desiccation at $75^{\circ} \mathrm{C}$.

illustrates the proportion of total energy derived from each class of substrate for an average male (182 g) and female $(270 \mathrm{~g})$ in this study. Energy produced from a substrate was calculated as the product of the mass of that substrate utilized and its energy equivalent in units of $\mathrm{kJ} / \mathrm{g}$. For carbohydrate, since not all the glucose liberated from glycogen was completely oxidized (note the pronounced increase in total body lactate, Fig. 5), half of the molar equivalent of the mass of lactate accumulated was subtracted to obtain the mass of glucose completely oxidized. The contribution to energy production by anaerobic glycolysis was then added.

The analysis indicated that the average female painted turtles utilized 2.5 times the energy as the average male (303.8 vs. $120.8 \mathrm{~kJ}$ ). However, the pattern of energy substrate utilization was similar in both sexes with energy derived from lipid providing approximately $56 \%$ of the energy. Protein and glycogen provided approximately 27 and $17 \%$, respectively.

The mass of the energy substrates used by turtles in this study was also converted to $\mathrm{O}_{2}$ consumption to provide an estimate of metabolic rate during the 179 days between the fall and spring samples. For the average $182 \mathrm{~g}$ male illustrated in Fig. 7, the rate of $\mathrm{O}_{2}$ consumption was $0.008 \mathrm{ml} \mathrm{O}_{2} \mathrm{~g}^{-1} \mathrm{hr}^{-1}$, while the average $270 \mathrm{~g}$ female could

\section{$270 \mathrm{~g}$ Female}
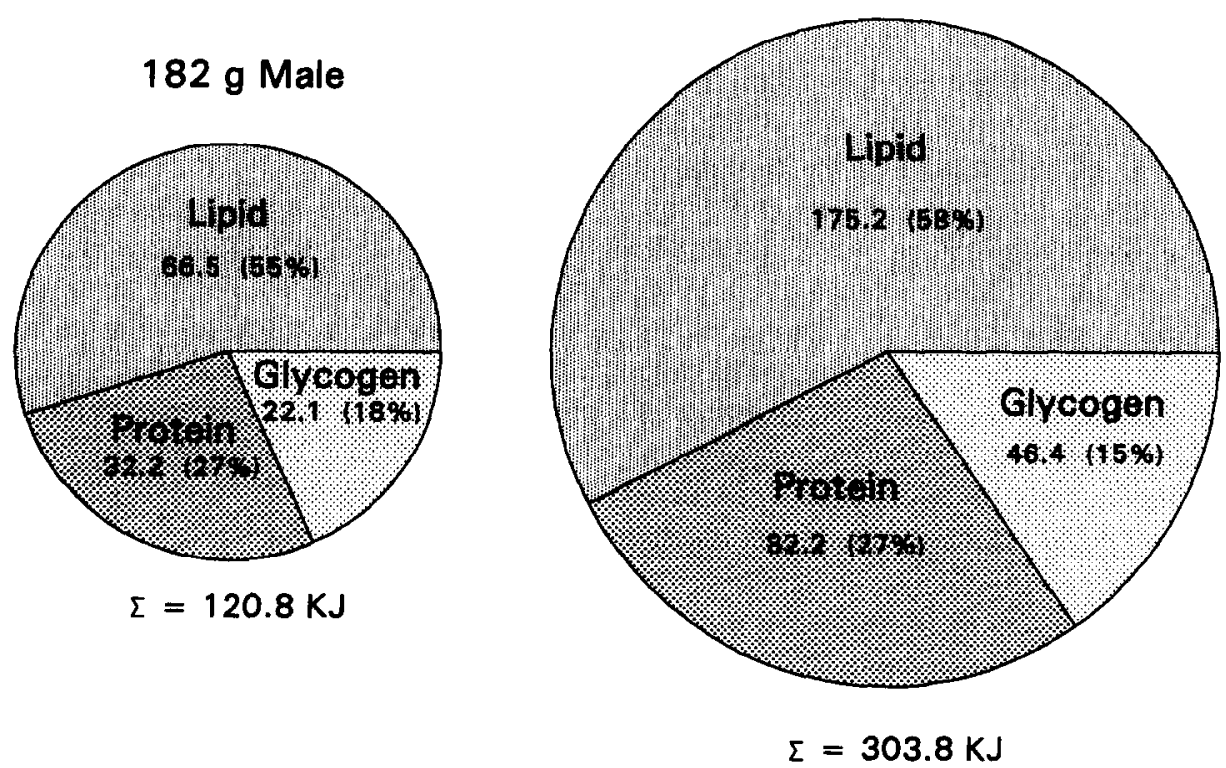

Fig. 7. Summary of energy substrate utilization of male and female painted turtles. The area of the pie represents the total energy expenditure of turtles of average mass in this study, assuming complete oxidation of each respective energy source. Note the contribution of glycogen is corrected by the incomplete metabolism to lactate. 
consume $0.013 \mathrm{ml} \mathrm{O}_{2} \mathrm{~g}^{-1} \mathrm{hr}^{-1}$. Thus, on a per gram basis, overwintering female turtles utilize $63 \%$ more energy than males.

\section{Discussion}

The results indicate that painted turtles utilized lipid, protein and glycogen as energy substrates between October and March sampling. Fat oxidation provided the predominance of energy in both male and female turtles (Fig. 7). This, however, was a reflection of the higher energy content of fat. On a mass basis, lipid and protein were utilized to approximately the same degree. Based on rates of substrate utilization, females used $63 \%$ more energy than males between the fall and spring sample. This finding is somewhat surprising, but may be partially due to the fact that the shell represents a lower percentage of total mass in females, and thus they possess a higher proportion of more metabolically active soft-tissue (data not shown). It could also be explained by an increased energetic cost associated with energy allocation for reproduction or by higher levels of activity during the overwintering period.

When the mass of depleted energy substrates was converted to $\mathrm{O}_{2}$ consumption, the values obtained $\left(0.008\right.$ and $0.013 \mathrm{ml} \mathrm{O}_{2}$ $\mathrm{g}^{-1} \mathrm{hr}^{-1}$ for males and females, respectively) were substantially greater than those reported in the literature for turtles at low temperatures. The standard metabolic rates of emydid turtles at $3-10^{\circ} \mathrm{C}$ range between 0.0011 and $0.0051 \mathrm{ml} \mathrm{O}_{2} \mathrm{~g}^{-1} \mathrm{hr}^{-1}$ (Rapatz and Musacchia, 1957; Gatten, 1974; Herbert and Jackson, 1985). Estimates of metabolic rate in this study, however, are for free-ranging, naturally acclimatized animals as opposed to laboratory measurements of temperature acclimated, resting turtles that were purchased from commercial dealers. Naturally, overwintering painted turtles would be expected to show substantially higher energy demands during the first half of the overwintering period October-December if they were still active and at body temperatures greater than those used in laboratory studies. To the best of my knowledge, there are no published reports of body temperatures for free rang- ing painted turtles in winter; however, turtles could regulate body temperature well above the $3-10^{\circ} \mathrm{C}$ range during the fall. For example, hibernaculum temperature does not fall below $10^{\circ} \mathrm{C}$ until late November-early December (Crawford, 1991). Turtles may also elevate body temperature in the fall through aerial basking. Although reports of winter activity are largely anecdotal, radiotelemetric studies of painted turtles indicate that movements continue throughout the fall and early winter with turtles not becoming dormant until January (Taylor and Nol, 1989). Painted turtles have also been reported to become active during periods of winter thaw (Sexton, 1959). Thus, the higher estimated metabolic rates derived in this study suggest that naturally overwintering turtles remained active and/or possessed body temperatures higher than $3-10^{\circ} \mathrm{C}$ during at least part of the overwintering period.

Despite the reliance upon neutral lipid to provide energy during overwintering, substantial reserves remained at the time of emergence. The dependence on fat as an energy source during hibernation apparently varies between species. Brisbin (1972) working with the box turtle, Terrapene carolina in outdoor pens in Georgia, found a lack of seasonal variation in body fat content. Even after the period of winter dormancy, no reduction in lipid was observed. McPherson and Marion (1982), however, found seasonal cycling of lipids in Sternotherus odoratus in central Alabama. Carcass lipids of males increased steadily throughout the activity season and then declined over the winter. The pattern was more complex in females due to the high lipid content of eggs and the laying of two clutches of eggs during the active season. However, a decline in carcass lipid was observed in females between November and March when turtles were not feeding (McPherson and Marion, 1982).

Female turtles possessed more body fat than males on either a wet or dry mass basis. This was especially true for larger females that were sexually mature and would presumably be gravid. Since approximately half of the energy in a clutch of eggs is already allocated to the follicles when a female enters hibernation 
(Congdon and Tinkle, 1982), the higher levels of lipid in females were probably due to the lipid content of their eggs.

Protein also contributed significantly to energy production in overwintering C. picta. When total carcass protein was expressed as percent lean dry mass, thus eliminating the complicating effects of changes in body water (Fig. 6) and neutral lipid (Fig. 1), protein fell $10.4 \%$ between the fall and spring samples.

No significant changes were found in the protein content of tissues examined (data not shown). Although the protein content of tissues (mg/g wet mass) did not change significantly, the overall mass of the tissue, and thus the total mass of protein in the tissue, may decrease. For example, Olson (1987) reported a decrease in tissue indices of both cardiac and pectoral muscle in $C$. picta between fall and spring in Michigan. Only the atrophy of pectoralis muscle was statistically significant. Previously, the contribution of protein to overwintering energetics has received little attention in turtles (Ultsch, 1989). It has been assumed that lipid and glycogen provided energy during overwintering; however, other reptiles apparently utilize protein during hibernation. For example, Costanzo (1985) reported that garter snakes used $34.2 \%$ and $55.3 \%$ of their starting liver and muscle protein during hibernation.

Glycogen was also significantly used by turtles between October and March. The use of carbohydrate can be seen by the decrease in total body glycogen, the decrease in the glycogen content of liver, and the large increase in total body and tissue lactate concentration. In the absence of oxygen, glycogen is hydrolyzed to provide glucose for energy production via anaerobic glycolysis with the subsequent production of lactate (Penney, 1987). The accumulation of lactate strongly suggests that hibernating turtles are exposed to prolonged periods of anoxia. This is supported by the observation that dissolved $\mathrm{O}_{2}$ fell below 1 ppm for an average of 43 days in a pond inhabited by $C$. picta in Michigan (Crawford, 1991). The use of glycogen may have been underestimated as glycogen seemed to be partially depleted in muscle in the fall sample. The glycogen content in the muscle of fall turtles was $22.0 \mathrm{mg} / \mathrm{g}$ wet mass in this study and, surprisingly, increased to $33.7 \mathrm{mg} / \mathrm{g}$ in spring. Daw et al. (1967) reported the glycogen content of pectoralis muscle to be $51 \mathrm{mg} / \mathrm{g}$ wet mass in resting normothermic painted turtles. The apparent increase in muscle glycogen may have been an artefact of the trapping method. Fall turtles were collected in basking traps, whereas spring turtles were dipnetted. Although traps were checked daily, some individuals may have been in the traps for up to $6 \mathrm{hr}$. Turtles in basking traps invariably show a high level of activity, and thus may deplete muscle glycogen especially in the pectoralis muscle which is used for swimming. This notion is further supported by the elevation in lactate in both whole body (Fig. 5) and pectoralis muscle $(1.38 \mu \mathrm{M} / \mathrm{g}$ wet weight $)$ in fall turtles.

Upon emergence, painted turtles had significantly higher body water contents than pre-hibernatory animals. The increase in body water seemed to offset the decrease in energy substrates. Whereas the source of the increase in body water may be from osmotic and/or metabolic water, the accumulation of water is due to changes in osmoregulatory function at the low body temperatures experienced during hibernation (Crawford, 1988, 1991). This hypothesis is supported by the observation that in the laboratory, painted turtles fasted at $26^{\circ} \mathrm{C}$ lost mass, whereas turtles fasted and maintained at $5^{\circ} \mathrm{C}$ gained mass (Morlock et al., 1972).

Turtles still retained significant energy reserves upon emergence in the spring. This may be an important reserve to meet the increased energy demands of activity and higher body temperatures after emergence, but before feeding can resume. It also indicates that turtles possess a reserve capacity possibly allowing them to hibernate in the most severe winters.

Acknowledgements-I wish to thank Dr William R. Dawson for his assistance and guidance in the pursuit of this study. The assistance of G. Breittenbach and the staff of the E. S. George Reserve in the collection of turtles was greatly appreciated. This research was supported by grants from the Department of Biology at the University of Michigan. 


\section{References}

Brisbin I. L. (1972) Seasonal variation in the live weights and major body components of captive box turtles. Herpetologica 28, 70-75.

Congdon J. D. and Tinkle D. W. (1982) Reproductive energetics of the painted turtle Chrysemys picta. Herpetologica 38, 228-237.

Constanzo J. P. (1985) The bioenergetics of hibernation in the eastern garter snake Thamnophis sirtalis. Physiol. Zool. 58, 682-692.

Crawford K. M. (1988) Osmoregulatory function in summer and winter acclimatized painted turtles Chrysemys picta. Ph. D. Dissertation. University of Michigan. 130 pp.

Crawford K. M. (1991) The winter environment of painted turtles, Chrysemys picta: temperature, dissolved oxygen, and potential cues for emergence. Can. J. Zool. 69, 2493-2498.

Daw J. C., Wenger D. P. and Berne R. M. (1967) Relationship between cardiac glycogen and tolerance to anoxia in the western painted turtle Chrysemys picta bellii. Comp. Biochem. Physiol. 22, 69-73.

Ernst C. H. (1972) Temperature-activity relationship in the painted turtle, Chrysemys picta. Copeia 217-222.

Gatten R. E., Jr. (1974) Effects of temperature and activity on aerobic and anaerobic metabolism and heart rate in the turtles Pseudenys scripta and Terrapene ornata. Comp. Biochem. Physiol. 48A, 619-648.

Gibbons J. W. (1968) Reproductive potential, activity and cycles in the painted turtle, Chrysemys picta. Ecology 49, 399-409.

Herbert C. V. and D. C. Jackson (1985) Temperature effects on the responses to prolonged submergence in the turtle Chrysemys picta bellii. II. Metabolic rate, blood acid-base and ionic changes, and cardiovascular function in aerated and anoxic water. Physiol. Zool. 58, 670-681.

MacCulloch R. D. and Secoy D. M. (1983) Demography, growth and food of western painted

30,10

urtles, Chrysemys picta bellii (Gray), from southern Saskatchewan. Can. J. Zool. 61, 1499-1509.

McPherson R. J. and Marion K. R. (1982) Seasonal changes of total lipids in the turtle Sternotherus odoratus. Comp. Biochem. Physiol. 71A, 93-98.

Morlock H., Herrington S. and Oldham M. (1972) Weight loss during food deprivation in the eastern painted turtle, Chrysemys picta picta. Copeia 392-394.

Olson J. M. (1987) The effect of seasonal acclimation on metabolic-enzyme activities in the heart and pectoral muscle of painted turtles Chrysemys picta marginata. Physiol. Zool. 60, 149-158.

Penney D. G. (1987) Frogs and turtles: different ectotherm overwintering strategies. Comp. Biochem. Physiol. 86A, 609-615.

Rapatz G. L. and Musacchia X. J. (1957) Metabolism of Chrysemys picta during fasting and during cold torpor. Am. J. Physiol. 188, 456-460.

Sexton O. J. (1959) Spatial and temporal movements of a population of the painted turtle, Chrysemys picta marginata (Agassiz). Ecol. Monogr. 29, $113-140$.

Taylor G. M. and Nol E. (1989) Movements and hibernation sites of overwintering painted turtles in southern Ontario. Can. J. Zool. 67, 1877-1881.

Ultsch G. R. (1989) Ecology and physiology of hibernation and overwintering among freshwater fishes, turtles and snakes. Biol. Rev. 64, 435-516. 